\title{
THE NEOGENE OF THE LOWER TAGUS BASIN (PORTUGAL)
}

Trabajo presentado a las XVIII Jornadas de Paleontología y

II Congreso Ibérico de Paleontología

Universidad de Salamanca

Salamanca, 24-29 de Septiembre de 2002

\author{
João PAIS
}

Centro de Estudos Geológicos, Departamento de Ciências da Terra, Faculdade de Ciências e Tecnologia, Quinta da Torre, 2829-516 Caparica, Portugal. http://www.dct.fct.unl.pt/CEGnovo/CEG.html. Email: jjp@fct.unl.pt.

Pais, J. 2004. The Neogene of the Lower Tagus Basin (Portugal). [El Neógeno de la Cuenca del Bajo Tajo (Portugal).] Revista Española de Paleontología, 19 (2), 229-242. ISSN 0213-6937.

\begin{abstract}
The Tertiary Lower Tagus Basin (LTB) occupies a large area in Portugal and constitutes a symmetric basin of the oriental huge Upper Tagus Basin, centered at Madrid (Spain).

The LTB was an endorreic basin during the Paleogene. Marine connection occurred at the Lower Aquitanian; at the Lisbon - Setúbal Peninsula region the sedimentation was in the ocean/continent interface, with several changes in the coast line. Apparently, the first marine transgression came from South, originating a gulf with a $\mathrm{N}-\mathrm{S}$ coral reef that attained the Lisbon area. Occidental communication to the sea was established after the Burdigalian.The sedimentary and palaeontologic record of the distal sector of the LTB (Lisbon-Setúbal Peninsula) is related to sea level changes. It is possible to correlate levels with planctic foraminifera and mammals, as well as to get isotopic ages (K/Ar in glauconites; $\left.{ }^{87} \mathrm{Sr} /{ }^{86} \mathrm{Sr}\right)$. Good biostratigraphic data can be obtain from continental and coastal deposits. The fossil richness - dinoflagellates, spores, pollen, plant macrorremains, foraminifera, ostracoda, molluscs, echinids, fishes, reptiles, mammals - and $\mathrm{O}$ and $\mathrm{C}$ isotopes, constitutes a large source of information for environmental and palaeogeographical reconstitutions, as well as for the establishment of correlations between marine and continental deposits. The analysis and the integration of a large amount of lithological and biostratigraphical data joined with isotopic ages (K/Ar and ${ }^{87} \mathrm{Sr} /{ }^{86} \mathrm{Sr}$ ), allow the establishement of a chronostratigraphic framework for the distal part of the Miocene of the LTB and the definition of 10 depositional sequences, in part agreeing with the Haq's 3rd order eustatic cycles. Climatic evolution during the Miocene has been also characterized. At continental environments, the faunas and floras point out to an alternation of moist and dry episodes, the dryest one at the Langhian.

For the inland, two sectors can be characterized. Near the region directly affected by the sea (Ribatejo and Alto Alentejo) deposits are related with the wandering of a Pre-Tagus in a large fluvial plain. During the Lower and Middle Miocene detrital sedimentation is well represented. Some marls with oysters denounce high eustatic sea levels; brackish waters attain regions $150 \mathrm{~km}$ far from the extant coast line. Some vertebrate fossils sites allow the establishment of correlations with the Lisbon region, namely during the Middle Miocene and Lower Tortonian. Sedimentary conditions changed at Lower Upper Miocene. At the right bank of the Tagus, limestones accumulate in lacustre and palustre environments; latteraly thick clay deposits strecht out to the left bank.

At the proximal areas of the LTB (Beira Baixa) the chronostratigraphical controle is poor. The outcrops are largely discontinuous. It only has been possible to define alostratigraphic units, bounded by regional unconformities, resulting from tectonic events recognized at the Iberia scale. During Lower and Middle Miocene, a sandy braided depositional system was installed, draining the fluvial plain of the Pre-Tagus from NE to SW. Plant macro-remains indicate a warmer and moister climate than today. Hispanotherium matritensis (steppe rhinoceros) is known from East of Castelo Branco (Plasencia, Spain); it is characteristic of MN5 zone (Astaracian) and is also known from Lisbon's Langhian. Younger deposits (Upper Tortonian and Messinian) correspond to alluvial fan sediments occur near tectonic slopes, at the base of rising mountains (Portuguese central chain); the thickness and granulometry quickly decrease downstream.

Pliocene fluvial deposits overlay through an erosion surface the marine Tortonian (Setúbal Peninsula) and the continental limestones and clays of the Vallesian of Ribatejo (inland). During the Zanclean the continental sedimentation carried on only at the proximal part of the basin (Beira Baixa) with the deposition of endorreic alluvial fan conglomerates. Away of the mountain feeder relieves, the sedimentation show a decrease of thickness; alternating conglomerates and sandy lutites were deposited. A temperate mediterranean climate with contrasting seasons prevailled. In the Piacenzian, alluvial fans and braided fluvial systems were installed draining to the Atlantic, preceding the actual hydrographical net. Feldspatic sands were deposited in the Setúbal Peninsula; the coast line was to the west of the actual. A transgression took place over the Occidental littoral, affecting the Lower Tagus (Setúbal
\end{abstract}


Peninsula) and the Mondego Basins. Whithish conglomerates with quartzite and quartz rounded clasts overlay the Piazencian sands of the Setúbal Peninsula. They yielded Pre-Acheulian artifacts allowing correlation with the PlioPleistocene boundary. Basin inland conglomerates with iron crusts point out to cold and dry environments.

Key words: Lower Tagus Basin, Neogene, Portugal, Palaeogeography, Biostratigraphy, Palaeoclimatology.

\section{RESUMEN}

La Cuenca del Bajo Tajo (LTB) ocupa una amplia extensión en Portugal, y constituye una cuenca simétrica de la amplia Cuenca del Tajo española.

LTB fue una cuenca de carácter endorreico durante el Paleógeno. Estuvo conectada con el mar durante el Aquitaniense inferior; en la región de la Península de Lisboa-Setúbal, la sedimentación tuvo carácter mixto marino/ continental, con varios cambios en la línea de costa. Aparentemente, la primera transgresión marina procedió del Sur, originando un golfo con un arrecife de coral elongado en dirección N-S que alcanzó la zona de Lisboa. La comunicación marina por el borde occidental se estableció después del Burdigaliense. El registro sedimentario y paleontológico del sector distal de LTB (Península de Lisboa-Setúbal) se ha relacionado con cambios del nivel del mar. Es posible la correlación entre niveles con foraminíferos planctónicos y con mamíferos, y edades isotópicas (K/Ar en glauconitas, ${ }^{87} \mathrm{Sr} r{ }^{86} \mathrm{Sr}$ ). Se pueden obtener buenos datos bioestratigráficos a partir de sedimentos continentales y costeros. La riqueza en fósiles - dinoflagelados, polen, esporas, macrorestos vegetales, foraminíferos, ostrácodos, moluscos, equínidos, peces, reptiles, mamíferos e isótopos estables de C y O constituye una gran fuente de información para reconstrucciones ambientales y paleogeográficas, así como para la correlación entre depósitos marinos y contintentales. El análisis y la integración de una gran cantidad de datos litológicos y bioestratigráficos, unidos a las dataciones isotópicas ( $\left.\mathrm{K} / \mathrm{Ar},{ }^{87} \mathrm{Sr} /{ }^{86} \mathrm{Sr}\right)$, ha permitido el establecimiento de la cronoestratigrafía para la parte distal del Mioceno de LTB, y la definición de 10 secuencias deposicionales, en parte correlacionadas con los ciclos eustáticos de tercer orden de Haq. Se ha caracterizado también la evolución climática durante el Mioceno. En ambientes continentales, las faunas y floras sugieren una alternancia de episodios húmedos y secos, produciéndose el más seco durante el Langhiense.

En dirección al continente, se pueden caracterizar dos sectores. Cerca de la región directamente afectada por el mar (Ribatejo y Alto Alentejo), los sedimentos están relacionados con la migración del pre-Tajo en una amplia llanura aluvial. Durante el Mioceno inferior y medio, la sedimentación detrítica está bien representada. La presencia de algunas margas con ostreidos se relacionan con periodos de alto nivel del mar; depósitos de aguas salobres alcanzan regiones situadas a $150 \mathrm{~km}$ de la actual línea de costa. Algunos yacimientos de vertebrados fósiles permiten el establecimiento de correlaciones con la región de Lisboa, sobre todo durante el Mioceno medio y el Tortoniense inferior. Las condiciones sedimentarias cambiaron en el Tortoniense inferior. En la margen derecha del Tajo se acumularon calizas lacustres y palustres; potentes depósitos arcillosos laterales se extienden hasta la margen izquierda.

En las zonas proximales de LTB (Beira Baixa), el control cronoestratigráfico es pobre. Los afloramientos son muy discontinuos. Únicamente ha sido posible definir unidades aloestratigráficas, limitadas por discontinuidades regionales, originadas por eventos tectónicos reconocidos a escala de toda Iberia. Durante el Mioceno inferior y medio se instaló un sistema deposicional trenzado de carácter arenoso, que drenó la llanura aluvial del pre-Tajo desde el NE hacia el SO. Los macrorrestos vegetales indican un clima más cálido y húmedo que el actual. Hispanotherium matritensis (rinoceronte de la estepa) procedente del este de Castelo Branco (Plasencia, España); es característico de la zona MN5 (Astaraciense), y también se encuentra en el Langhiense de Lisboa. Depósitos más recientes (Tortoniense superior y Messiniense) correspondientes a abanicos aluviales asociados a pendientes tectónicas, se encuentran en la base de elevaciones montañosas (Cadena Central portuguesa); el espesor y el tamaño de grano disminuyen rápidamente hacia sus tramos distales.

Los sedimentos fluviales del Plioceno se sitúan de un modo disconforme tanto sobre los del Tortoninese marino (península de Setúbal) como sobre las calizas y arcillas continentales del Vallesiense de Ribatejo (hacia el continente), delimitándose entre ambos una superficie de erosión. Durante el Zancliense, la sedimentación continental tuvo lugar sólo en la zona proximal de la cuenca (Beira Baixa), con sedimentación de abanicos aluviales conglomeráticos de carácter endorreico. Distalmente a los relieves montañosos que proporcionan materiales, el espesor de los sedimentos disminuye, alternando conglomerados y lutitas arenosas. El clima fue de tipo mediterráneo templado con alta estacionalidad. En el Piacenciense, los abanicos aluviales y los sistemas fluviales trenzados se instalaron drenando hacia el océano Atlántico, precediendo la actual red hidrográfica. Se depositaron arenas ricas en feldespatos en la península de Setúbal, y la línea de costa se situó más al oeste que la actual. Una transgresión tuvo lugar sobre todo el litoral occidental, afectando a las cuencas del Bajo Tajo (península de Setúbal) y del Mondego. Conglomerados blancuzcos con clastos redondeados de cuarcita y de cuarzo se sobreimponen a las arenas del Piacenciense de la península de Setúbal. Contienen artefactos pre- 
Achelenses que sugieren una correlación con el límite Plio-Pleistoceno. La presencia hacia el centro de cuenca de conglomerados con cortezas ferruginosas sugieren ambientes fríos y secos.

Palabras clave: Cuenca del Bajo Tajo, Neógeno, Portugal, Paleogeografía, Biostratigrafía, Paleoclimatología.

\section{INTRODUCTION}

In Iberia, several grabens were opened during the Paleogene, some of which evolved to large sedimentary basins along the Cenozoic.

After the Maastrichtian the sedimentation took place only in the Mondego Tertiary basin, north of the Nazaré fault (a NE-SW reactivated hercynian fault) a fossiliferous level with mammals of Upper Paleocene to Lower Eocene age occurs in Silveirinha (Antunes and Russell, 1981; Antunes et al., 1997). Paleocene and Lower Eocene seem not to be represented in other regions.

The Lower Tagus Basin (LTB) occupies a large area in Portugal, from the littoral region of Lisbon-Setúbal Peninsula, to beyond spanish border near Castelo Branco (Beira Baixa). The LTB is a symmetrical, western counterpart of the oriental large Upper Tagus Basin, centered at Madrid (Spain). Three distinct sectors can be recognized:

- Soudwesthern distal sector, in the Lisbon and Setúbal Peninsula, in close relationship with the ocean;

- central sector in Ribatejo e Alto Alentejo, with continental facies and some brackish episodes corresponding to the higher eustatic sea levels;

- Northern proximal sector in Beira Baixa, crossing the Portugal-Spain border, with continental facies only (Fig 1).

Lisbon and Setúbal Peninsula are located at the distal part of the Basin. Miocene sedimentation corresponds to time and space shifting interfaces between marine and continental domains. Miocene beds were well exposed. It is not surprising that geologic observation has been carried on since long ago (Almeida, 1762). An important period of research concerns early 19 th century and José Bonifácio de Andrada e Silva, then in charge of Mining and Metallurgy. Among his activities there is the reopening of gold mining at Adiça, a former medieval exploitation. An account of this, including the first description of sections where Miocene beds outcrop, was presented (Silva, 1817).

Gold exploitation at Adiça went on under WilhelmLudwig, baron von Eschwege. His geologic, mining and palaeontologic observations were published (Eschwege, 1831; with extra plates about marine miocene vertebrate fossils added by Alexandre Vandelli). For the first time, a generalized section between Sintra and Arrábida and concerning part of the Basin was produced (Op. cit.).

The next step in the study of the Lower Tagus Basin's Neogene is due to Daniel Sharpe $(1834,1841)$ who described units as the Almada beds that correspond to the mostly marine Miocene infillings. Early correlation attempts with Miocene units in France, Switzerland, Italy and

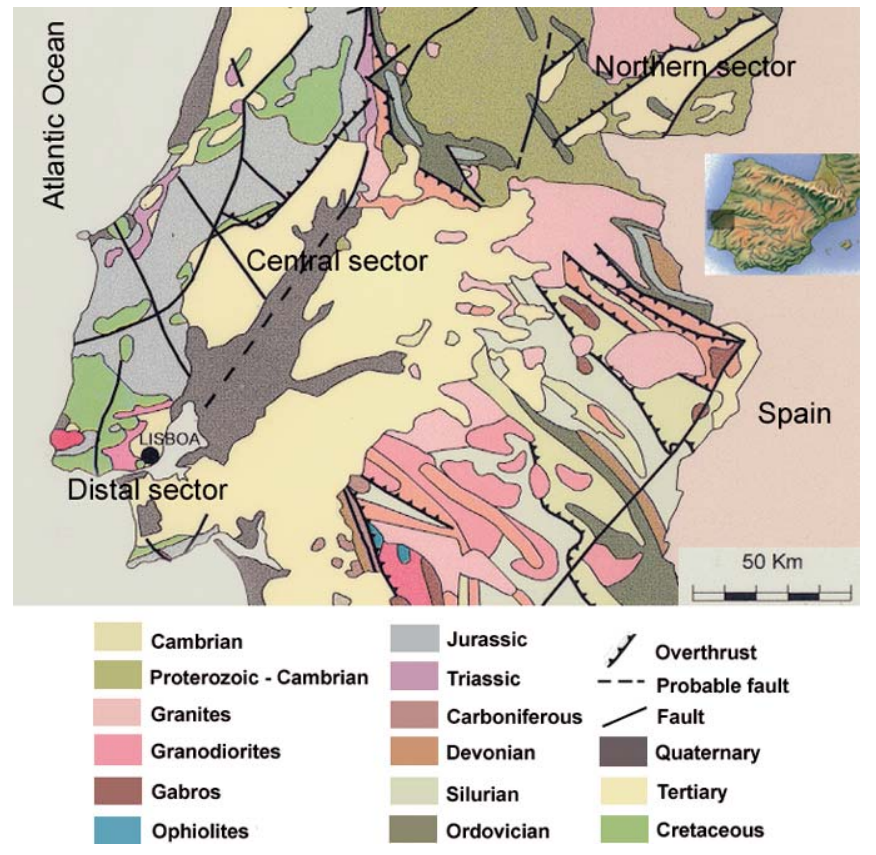

Figure 1. Lower Tagus Basin.

Austria were based on molluscs, partly described by G.B. Sowerby (in Smith, 1847). There were nearly no more British contributions ever since. They were succeded by papers by Portuguese and other, mostly French researchers.

An increase in research on Miocene beds was accomplished by the 2nd Commissão Geologica (1857-1868), by Carlos Ribeiro (field work) and F. Pereira da Costa (molluscs). The stratigraphic framework was basically that of Sharpe, whose Almada beds appeared under "Miocène moyen et supérieur/ III.- Formation marine avec fossiles analogues à ceux du bassin méditerranéen et des environs de Vienne en Autriche" (Ribeiro, 1878).

An hallmark in portuguese stratigraphy is the sketch on the marine Miocene by J.C. Berkeley Cotter, who was in charge of the Tertiary at the Geologic Survey (Cotter, 1904 in Dollfus et al., 1903-1904; Cotter, 1956). His classification of the Lisbon Miocene units is still in use (lithostratigraphic units designed "Divisions" from I to VII with some sub-units). Stratigraphic work was accompanied by high-standard palaeontologic research by swiss (Oswald Heer) and mostly by french authors (P. de Loriol, Gustave Dollfus, Frederic Roman).

There were also contributions by P. Choffat (Choffat, 1950, posthumous paper; 1:20000 geologic map of Lisbon). His chapter about marine Miocene (ibid.) is largely an abridged version of Cotter's.

Georges Zbyszewski restored the studies on the portuguese Tertiary since 1937 . Among many other con- 


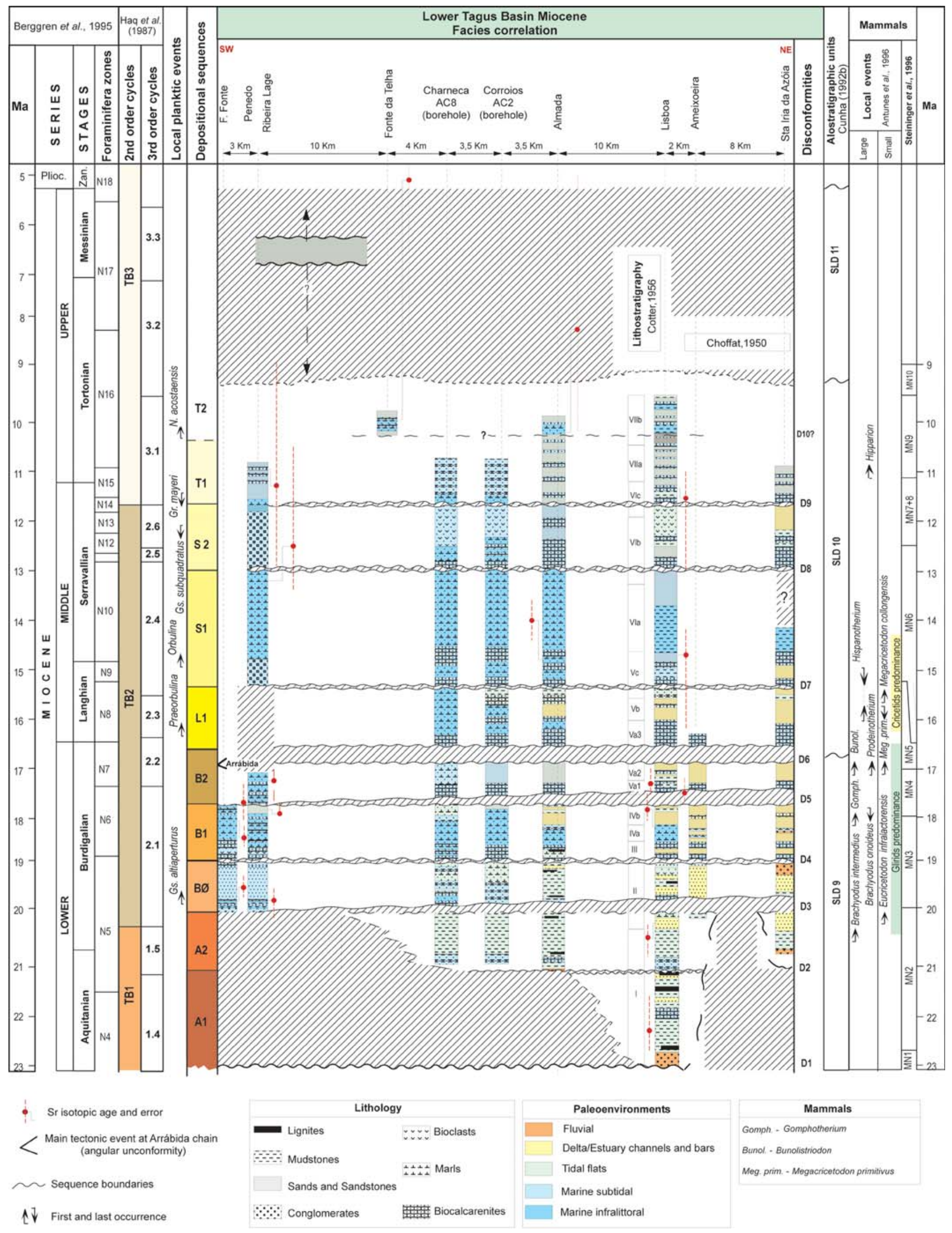

Figure 2. Chronostratigraphical framework for the Miocene of the distal sector of the Lower Tagus Basin (Antunes et al., 2000). 
tributions, there are some broad scope ones (Zbyszewski, 1954a, 1957, 1962, 1963, 1964 a, 1964b, 1967).

The development of studies on sedimentation led to new concepts. Rythmic sedimentation, erosion and sedimentation cycles, sequences and corresponding types became in fashion. This had consequences for the Lower Tagus basin. A high resolution stratigraphic strategy was deviced (M.T. Antunes), comprising: (a) detailed studies on important sections (Antunes and Torquato, 1969-1970, and latter contributions); (b) the improvement of datation and other data by means of biochronologic research, mostly on mammals and planktic foraminifera, K-Ar and (later) Sr isotope ages, sedimentology, palaeoecology, magnetostratigraphy, etc, rendering possible the development of regional synthesis and broad-scale correlations (Antunes et al., 1973, 1987, 1996a, 1996b; Antunes and Pais, 1992; 1993; a series of Notes about the Geology and Palaeontology of the Miocene of Lisbon, Antunes et al., since 1960). Azevêdo (1983) studied mainly the Pliocene deposits of Setúbal Peninsula.

Fewer studies had been produced about the inland part of the Lower Tagus Basin. Ribeiro (1880) described the stratigraphy of the continental Tertiary of the Ribatejo. Roman and Torres (1907) presented the first paleontologic data and a stratigraphic synthesis. Later works were produced by Zbyszewski (1941, 1943, 1946, 1947, 1953, 1954b, 1964a, 1964b, 1965, 1967b, 1967c, 1968). Antunes, alone or with others, pursued studies on the stratigraphy and the palaeontology of the Ribatejo area (Alberdi et al., 1978; Antunes, 1984; Antunes and Mein, 1977, 1979; Antunes and Mazo, 1983; Antunes et al.,1983, 1987, 1992; Antunes and Zbyszewski,1973). Palaeobotanical studies were first published by Heer (1881) and later pursued by Teixeira (1942a, 1942b, 1944a, 1944b, 1944c, 1944-1947, 1946, 1947a, 1947b, 1949, 1952a, 1952b, 1954, 1973, 1973-74, 1979); Pais followed these works (1972, 1973, 1978, 1979, 1981, 1986, 1987, 1989, 1991, 1999; Pais et al., 1999). Diniz $(1967,1984)$ and Diniz and Sivak (1979) characterized the palynology of the Rio Maior diatomites and lignites. Sedimentological studies have been produced by Carvalho (1968). Cunha $(1992,1992 b)$ characterized alostratigraphic unities and latter described the Cenozoic of the LTB proximal area (Beira Baixa) (Cunha, 1996); Barbosa (1995) recognised the alostratigraphy and the litostratigraphy of the Ribatejo continental deposits. More recently, Cunha (2000) described the alteration and cementation processes of the Tertiary deposits of Central Portugal including those of the LTB.

\section{DISTAL SECTOR OF THE LOWER TAGUS BASIN (LISBON AND SETÚBAL PENINSULA REGIONS)}

The LTB was an endorreic basin during the Paleogene. Marine conection occurred at the Lower Aquitanian; at the Lisbon - Setúbal Peninsula region the sedimentation was in the ocean/continent interface, with several changes in the coast line. Apparently, the first marine transgression came from South, originating a gulf with a N-S coral barrier reef that attained the Lisbon area. Westhern communication to the sea was established after the Burdigalian.

The sedimentary and palaeontologic record of the distal part of the LTB (Lisbon-Setúbal Peninsula) is related to sea level changes. Good biostratigraphic data can be obtained from continental and coastal deposits. It is possible to correlate levels with planktic foraminifera and mammals, as well as to obtain isotopic ages (K/Ar in glauconites; ${ }^{87} \mathrm{Sr} /{ }^{86} \mathrm{Sr}$ ). The fossil richness - dinoflagellates, spores, pollen, plant macrorremains, foraminifera, ostracoda, molluscs, echinids, fishes, reptiles, mammals - and $\mathrm{O}$ and $\mathrm{C}$ isotopes, constitutes a large and broad scope source of information for environmental and palaeogeographical reconstitutions, as well as for correlations between marine and continental deposits.

The analysis and the integration of large amount of lithological and biostratigraphical data such as the first and last occurrence of most significative taxa of foraminifera, ostracoda and mammals, together with isotopic ages (K/Ar and ${ }^{87} \mathrm{Sr} /{ }^{86} \mathrm{Sr}$ ) allow the establishement of an accurate chronostratigraphic frame for the distal part of the Miocene of the LTB and the definition of 10 depositional sequences that, at least in part, seem to correspond to Haq's 3rd order eustatic cycles. For more detailled data see Antunes et al. (1996b, 1999, 2000) and Legoinha (2001). A general stratigraphic frame for the Miocene is presented (Fig. 2, Fig. 3).

Climatic evolution during the Miocene has also been characterized. Tropical conditions prevailed in the sea. In the Upper Burdigalian and Langhian the temperature attained a maximum, being similar to that of today's Guinea gulf. The temperature decreased later, its values being similar to those of extant Morrocco sea waters. The continental faunas and floras point out to alternation of moist and dry episodes, the dryest one at the Langhian (Antunes and Pais, 1984; LauriatRage et al., 1993; Pais 1999) (Fig. 4).

In the Pliocene, a general regression occurred. Fluvial deposits overlay through an erosion surface the marine Tortonian in the Setúbal Peninsula. The fluvial Santa Marta Sands arrived to Setúbal peninsula. A short transgression took place over the westhern littoral in the Lower Tagus (Setúbal Peninsula) and the Mondego Basins. Brackish waters entered the Setúbal Peninsula (Azevêdo, 1983); clays with gypsum, plant macroremains, oysters, and Dreissena (identified by P. Callapez, Coimbra Univ.,) occur. Whitish conglomerates (Belverde Conglomerate) with rounded quartzite and quartz clast and some windblown clasts overlay the Piazencian sands of the Setúbal Peninsula. These conglomerates yielded Pre-Acheulian artifacts that point out to an age close by the PlioPleistocene boundary.

The correlation of these units with those of the LTB inland areas is presented (Fig.4). 


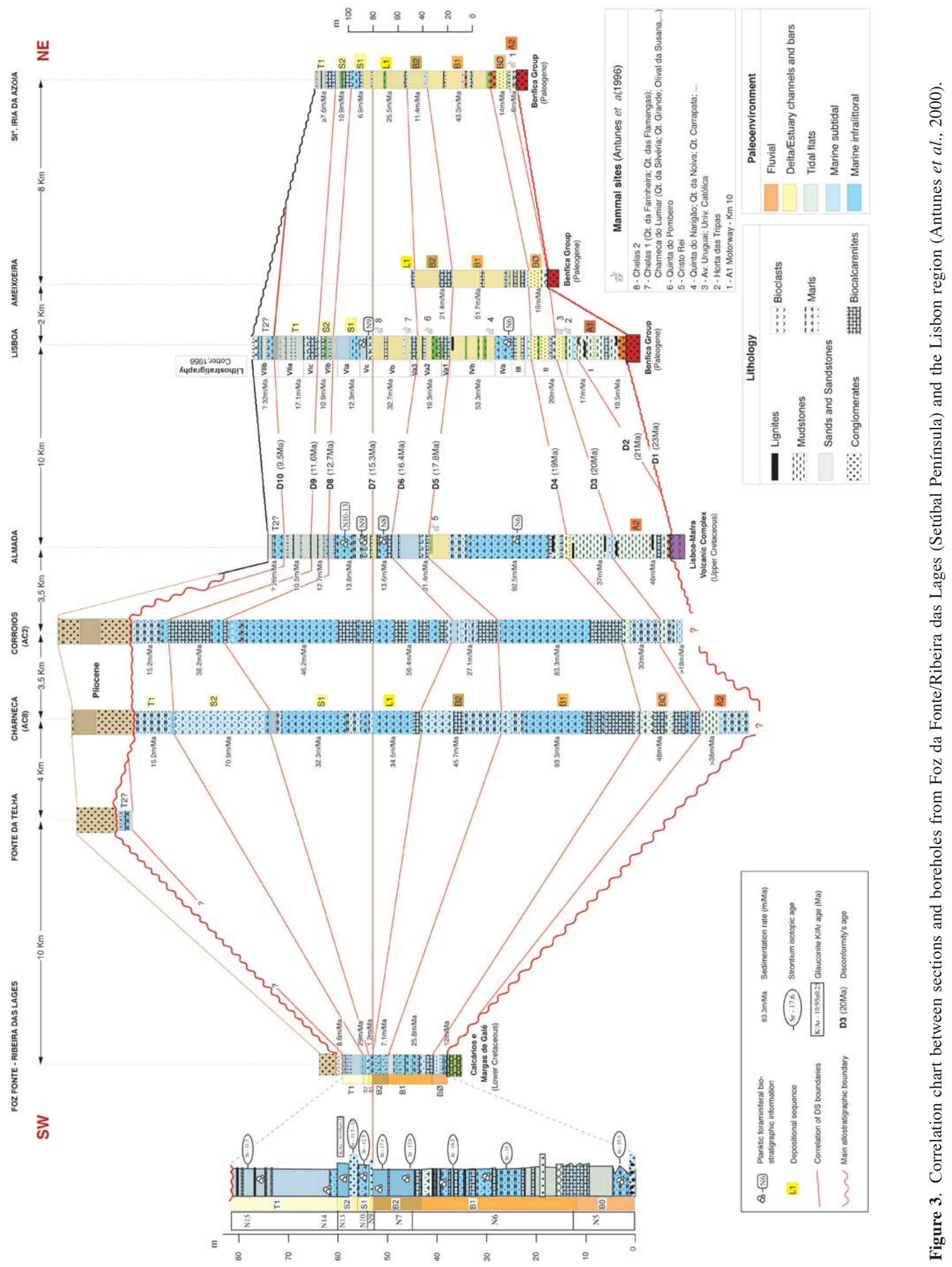




\section{CENTRAL SECTOR OF THE LOWER TAGUS BASIN (RIBATEJO AND ALTO ALENTEJO)}

Two main sectors can be characterized inland of the LTB. To the NE of the the distal region (Ribatejo and Alto Alentejo) deposits are related with the wandering of a PreTagus in a large fluvial plain (intermediate region). The proximal area of the basin is situated at Beira Baixa, crossing the Portugal - Spain border. Coarse proximal continental deposits occur.

Paleogene deposits (Grés de Monsanto) (Barbosa, 1995) are the basement of the Neogene. They outcrop in the borders of the basin and comprise coarse sandstones and some conglomerates in metric positive sequences. Calcretes and lacustre limestones (Quinta da Marquesa, Alcanede Limestones) occur at the top. Paligorskite and smectite predominate in the clay fractions.

During the Lower and Middle Miocene fluvial sedimentation is well represented (Ota Formation) overlaying the "Grés de Monsanto" through a regional unconformity. Some clays with oysters suggest high eustatic sea levels; brackish waters reaching regions $150 \mathrm{~km}$ far from the extant coast line. Some vertebrate fossil sites with mammals allow the establishment of correlations with the Lisbon region, namely during the Middle Miocene and Lower Tortonian. The main fossil localities are: Vila Nova da Rainha (MN5) (Alberdi et al., 1978); Póvoa de Santarém (MN6) (Soulié-Märsh, 1978; Pais, 1978; Antunes and Mein 1977; Truc, 1977; Gaudant, 1977); Casais da Formiga (MN7) (Alberdi et al., 1978); Archino (MN9) (Alberdi et al., 1978); Azambujeira inferior (MN9) (Antunes et al., 1983). At the top, faunas with Hipparion allow correlation with the zone MN9 (Lower Vallesian) (Antunes, 1979; Antunes and Ginsburg, 1983; Antunes et al., 1993). Kaolinite and illite predominate in the clay minerals.

Sedimentary conditions changed during early Upper Miocene. At the right bank of the Tagus, lacustrine and palustrine limestones occur (Almoster-Santarém Limestones); latteraly thick clay deposits (Tomar clays) strecht out to the left bank also. Almoster-Santarém Limestones are gray to whitish in colour; breccia structures are frequent; sandy and lutitic facies may occur. Smectite and illite predominate in the clay fraction. Tomar clays are represented by orange or red lutites with illite and kaolinite. Both constitute the Almoster Aloformation.

During Pliocene, fluvial arkosic sands (Ulme Formation) related with the wandering of the Pre-Tagus were deposited mainly at the left bank of the river. They overlay the Vallesian continental limestones (Almoster-Santarém limestones) and clays (Tomar clays) of Ribatejo and Alto Alentejo. The arkosic sands present some yellow to redish colour and a medium to coarse granulometry with low kaolinite and illite contents. The sands can be followed to the Setúbal Penin- sula where they correspond to the Santa Marta sands (Barbosa and Pena dos Reis, 1989, 1996; Barbosa, 1995). Some plant macroremain localities are known.

Locally, conglomerates occur (Rio de Moinhos Conglomerates, Martins et al., 1998) over the Almoster Aloformation. Two sequences can be recognised. The first one overlay the Monsanto Formation (Paleogene) or the Paleozoic. The MPS changes from $80-90 \mathrm{~cm}$ to $35-40 \mathrm{~cm}$. The upper levels are lutitic. The second conglomeratic sequence is mainly quartzitic. The MPS is around $50-40 \mathrm{~cm}$. A $10 \mathrm{~m}$ lutitic deposits complete the sequence (Barra et al., 2000).

To the NE of the intermediate area of the LTB, coarse conglomerates (Conglomerates of Serra de Almeirim) were deposited. The MPS changes from $45 \mathrm{~cm}$ in proximal areas to $10 \mathrm{~cm}$ in the more distal ones (Almeirim). Channel structures are frequent. Kaolinite prevails over illite (Barbosa, 1995; Barra et al., 2000).

The Vila de Rei Conglomerates (Upper Pliocene to Pleistocene), overlay by unconformity the Serra de Almeirim Conglomerates. The clasts are quartzitic, heterometric, and poorly rounded. The matrix is sandylutitic orange to red in colour, presenting iron cementation that suggests cold and dry environments. They have a fan-like structure developped near the Ordovician quartzitic crests at the North border of the Lower Tagus Basin (Barra et al., 2000). Correlations with distal and proximal regions are presented (Fig. 5).

\section{THE NORTHERN PROXIMAL SECTOR OF THE LOWER TAGUS BASIN (BEIRA BAIXA)}

The chronostratigraphical controle is poor in the LTB proximal areas (Beira Baixa). The outcrops are largely discontinuous. It has been possible to define alostratigraphic units bounded by regional unconformities (UBS) related with tectonic events recognized at iberian scale (Cunha,1992a, 1992b, 1996, 2000).

Conglomeratic and sandy arkosic deposits (Cabeço do Infante Formation) (Cunha, 1992a, 1996) have been correlated with the Paleogene Benfica Formation in the distal and Monsanto Sandstones of the intermediate LTB areas.

During Lower and Middle Miocene, a sandy braided depositional system was installed, draining the fluvial plain of the Pre-Tagus from NE to SW till the Ribatejo. Orange sands and green lutites with scarce fossils were deposited (Silveirinha dos Figos Formation) (Cunha, 1992a; 1996). These deposits overlay through an unconformity the Cabeço do Infante Formation or, by an angular unconformity, the Paleozoic of the Hesperic massif. Large channels with one hundred meters are typical (Cunha, 2000). Plant macro-remains colleted at Ponte de Sor suggest a warmer and moister than today climate (Pais, 1973,1981, 


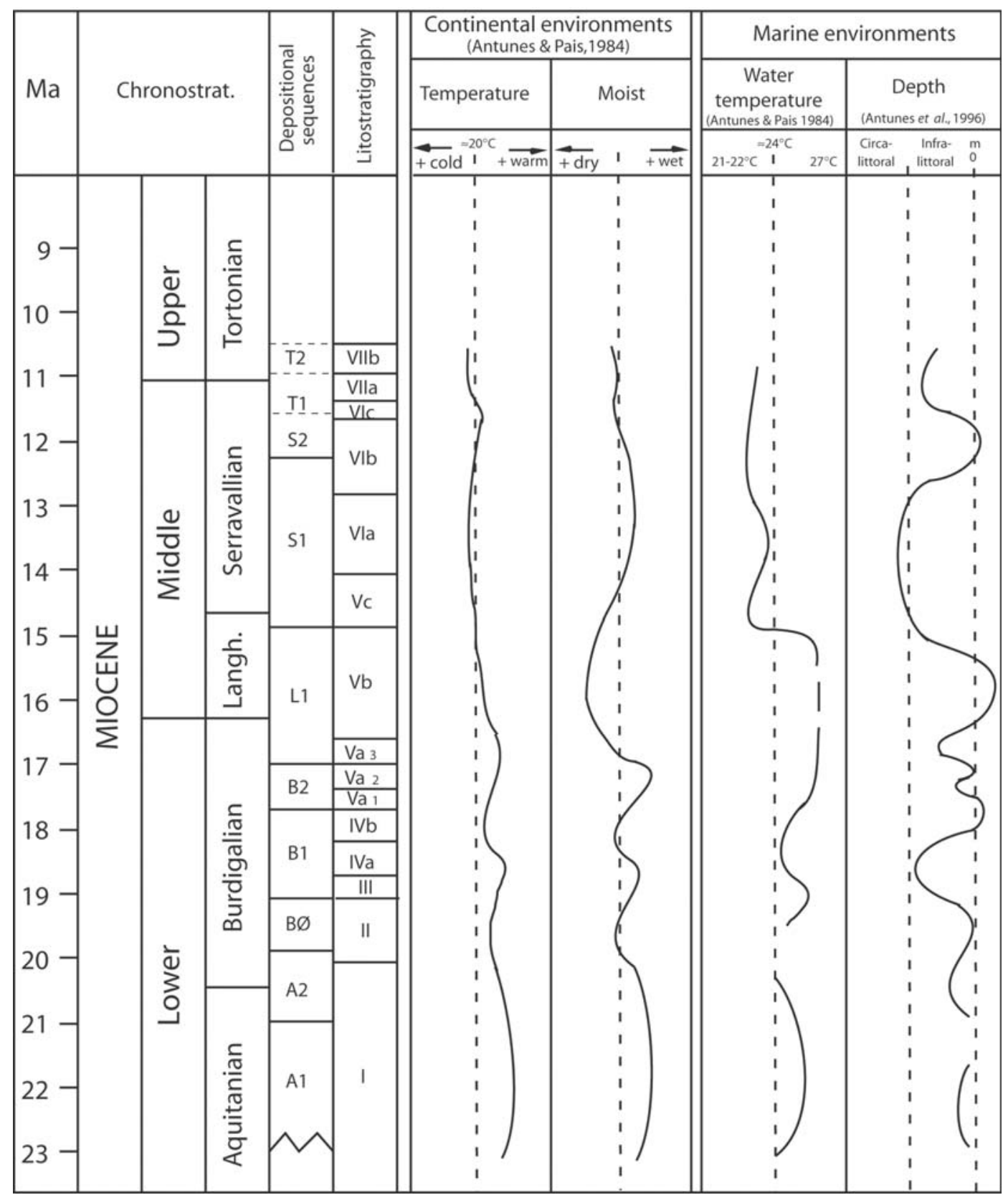

Figure 4. Paleoenvironmental conditions at the distal region of the Lower Tagus Basin during the Miocene (Pais, 1999).

1986). Silicified wood belonging to a tropical arboreal angiosperm indicates a warmer than today, and wet climate (Pais, 1973, 1983; Teixeira and Pais, 1976). To the East of Castelo Branco, at Plasencia (Cáceres, Spain), conglomerates and orange to red clays yielded Hispanotherium matritensis (Hernandez-Pacheco and Crusafont, 1960), a steppe rhinoceros known also at Lisbon in the L1 depositional sequence (Div. Vb) (Antunes, 1979; Antunes et al., 1999) and at Quintanelas and at Amor (Leiria, Mondego Basin) (Antunes and Ginsburg 1983; Antunes and Mein, 1981), MN5 mammal zone (Middle Aragonian). These arcosic deposits probably are correlative of the Ota Formation of the Ribatejo area (Carvalho, 1968; Antunes in Ribeiro et al., 1979; Cunha, 1992a; Barbosa, 1995).
Above the Silveirinha dos Figos Formation, alluvial fan sediments occur near tectonic slopes, at the piedmont of the rising mountains of the Portuguese central chain (Murracha Group, Upper Miocene to Pliocene); the thickness and granulometry quickly decrease downstream. The Murracha Group corresponds to two positives megasequences followed by a negative one, bounded by sedimentary unconformities (alostratigraphic units UBS 11, UBS 12 and UBS 13; Cunha, 1992b, 1996, 2000). From the bottom to the top, it includes the Torre, Monfortinho and Falagueira Formations.

Torre Formation presents conglomerates at the base and grayish green to yellowish micaceous sandy-lutites to the top, locally cemented by silica and green to redish in colour. The Formation disappears progressively to SE; 
Smectite with some illite predominate. Torre Formation corresponds to the UBS 11 and was interpreted as an alluvial endorreic system (Cunha, 1996, 2000).

During the Zanclean the continental sedimentation is well documented at the proximal part of the basin (Beira Baixa) with the deposition of endorreic alluvial fan conglomerates (Monfortinho Formation). Away from the mountains, there is a decrease of thickness; conglomerates and sandy lutites alternate. A temperate mediterranean climate with contrasting seasons prevailed. Monfortinho Formation is represented by red alluvial fan deposits with conglomerates and sandy-lutites facies. Illite and kaolinite predominate. It corresponds to the UBS 12 (Cunha, 2000).

Falagueira Formation (Piazencian) is represented by ocre to redish or whitish coarse deposits with a sandy to silty matrix. It constitutes a negative sequence reflecting the progradation of coalescent alluvial and braided sandy fluvial systems draining to the Atlantic and preceding the extant hydrographical net (Cunha et al., 1993). Kaolinite and some illite are represented in the clay fraction. The Falagueira Formation correspond to the UBS 13 (Cunha, 1996, 2000) and can be correlated with the Serra de Almeirim Conglomerates (Barbosa and Pena dos Reis, 1989).

Correlations with distal and intermediate regions are presented in figure 5 .

\section{PALAEOGEOGRAPHIC EVOLUTION}

First paleogeographic reconstitutions for the LTB distal area was presented by Antunes (in Ribeiro et al., 1979). New data, including those from the Belverde Borehole (Pais et al., 2002; Legoinha et al., 2002) and the characterization of alostratigraphic units in the intermediate and proximal areas, allow the establishement of new paleogeographic schematic maps for the evolution of the LTB (Fig 7).

During the first Miocene transgression event the sea attained the inner part of the Setúbal Peninsula; a gulf, reaching Lisbon area, was developed. Seismic profiles and the data concerning the Belverde Borehole, suggests that the sea entrance was made from the south. A N-S coral reef barrier developed shortly afterwards. The westwards opening of the Tagus gulf only happened in Lower Burdigalian (begining of the B1 depositional sequence). A marine N-S bank, corresponding to the extant coastal area, protected the inner region of the Setúbal Peninsula; the subsidence allowed the deposition of circa $1000 \mathrm{~m}$ of Neogene sediments, although in the N-S sea bank, only around $200 \mathrm{~m}$ are known.

During high sea level events (Burdigalian and Serravallian), brackish waters extended till $150 \mathrm{~km}$ inland to the intermediate region. Arrábida became an island during the Burdigalian and the Serravallian transgressions; the same occured with Sintra igneous massif (W of Lisbon) during the Serravallian (Figs. 7B, 7C).

Inland, the Tagus wandered through a large alluvial plain during Lower and Middle Miocene (Fig. 6, A, B and C). At the Lower Tortonian (C), a large marsh area developed in the Ribatejo. Lacustrine and palustrine limestones (Almoster-Santarém Limestones) as well as marls and clays (Tomar Clays) were the resulting main deposits.

During the Pliocene, a general regression occured. Fluvial sands arrived to the Setúbal Peninsula (Ulme sands). In the more proximal areas coarse conglomerates prograded to SW (Serra de Almeirim and Falagueira Conglomerates) (Fig. 6D).

\section{AKNOWLEDGEMENTS}

M.T Antunes, P. Legoinha and P. Cunha helped in the revision of the text and are gratefully acknowledged.

Projects aproved by the "Fundação para a Ciência e a Tecnologia" and by the POCTI cofunded by the EC FEDER Program: "POCTI/32345/CTA/2000 - Recognition of the Miocene of the distal region of the Lower Tagus Basin through a borehole with continuous sampling and "POCTI/CTA/38659/ 2001 - The Tertiary of central-northern Portugal basin analysis, stratigraphy and resources"

\section{REFERENCES}

Alberdi, M.T., Antunes, M.T., Sondaar, P.Y. et Zbyszewski, G. 1978. Les Hipparion du Portugal. Ciências da Terra (UNL), 4, 129-156.

Almeida, T. 1762. Recreasaõ Filozofica, ou Dialogo Sobre a Filozofia Natural para instrusaõ de pesoas curiozas, que naõ frequentáraõ as aulas. Tomo VI e ultimo. Trata dos Ceos e do Mundo. Na Oficina de Miguel Rodrigues. Lisboa, Tarde XXXV, 400-418.

Antunes, M. T. 1979. "Hispanotherium fauna" in Iberian Middle Miocene, its importance and paleogeographical meaning. Annales. Géologie des Pays Helléniques, t. hors sér. I, 19-26.

Antunes, M.T. 1984. Essai de synthèse sur les mammifères du Miocène du Portugal. Vol. d'hommage au géologue G. Zbyszewski, Ed. Recherche sur les Civilisations, Paris, 301-323.

Antunes, M.T., Casanovas, M.L., Cuesta, M.A., Checa, L., Santafé, J.V. and Agustí, J. 1997. Eocene Mammals from Iberian Peninsula. In: Actes dus Congr. BiochroM'97 (Edit. J.P. Aguilar, S. Legendre and J. Michaux). Memoires du Travaux E.P.H.E., Institut de Montepellier, 21, 337-352.

Antunes, M.T., Calvo, J.P., Hoyos, M., Morales, J., Ordoñez, S., Pais, J. y Sese, C. 1987. Ensayo de correlación entre el Neógeno de las áreas de Madrid y Lisboa (Cuencas Alta y Baja del rio Tajo). Comunicações dos Serviços Geológicos de Portugal, 73, 85-102.

Antunes, M.T., Civis, J., Gonzalez-Delgado, J.A., Legoinha, P. Nascimento, A. and Pais, J. 1996a. Miocene stable isotopes $\left(\delta^{18} \mathrm{O}, \delta^{13} \mathrm{C}\right)$ biostratigraphy and environments in the southern limb of the Albufeira syncline (Setúbal Peninsula, Portugal). Geogaceta, 21, 21-24. 


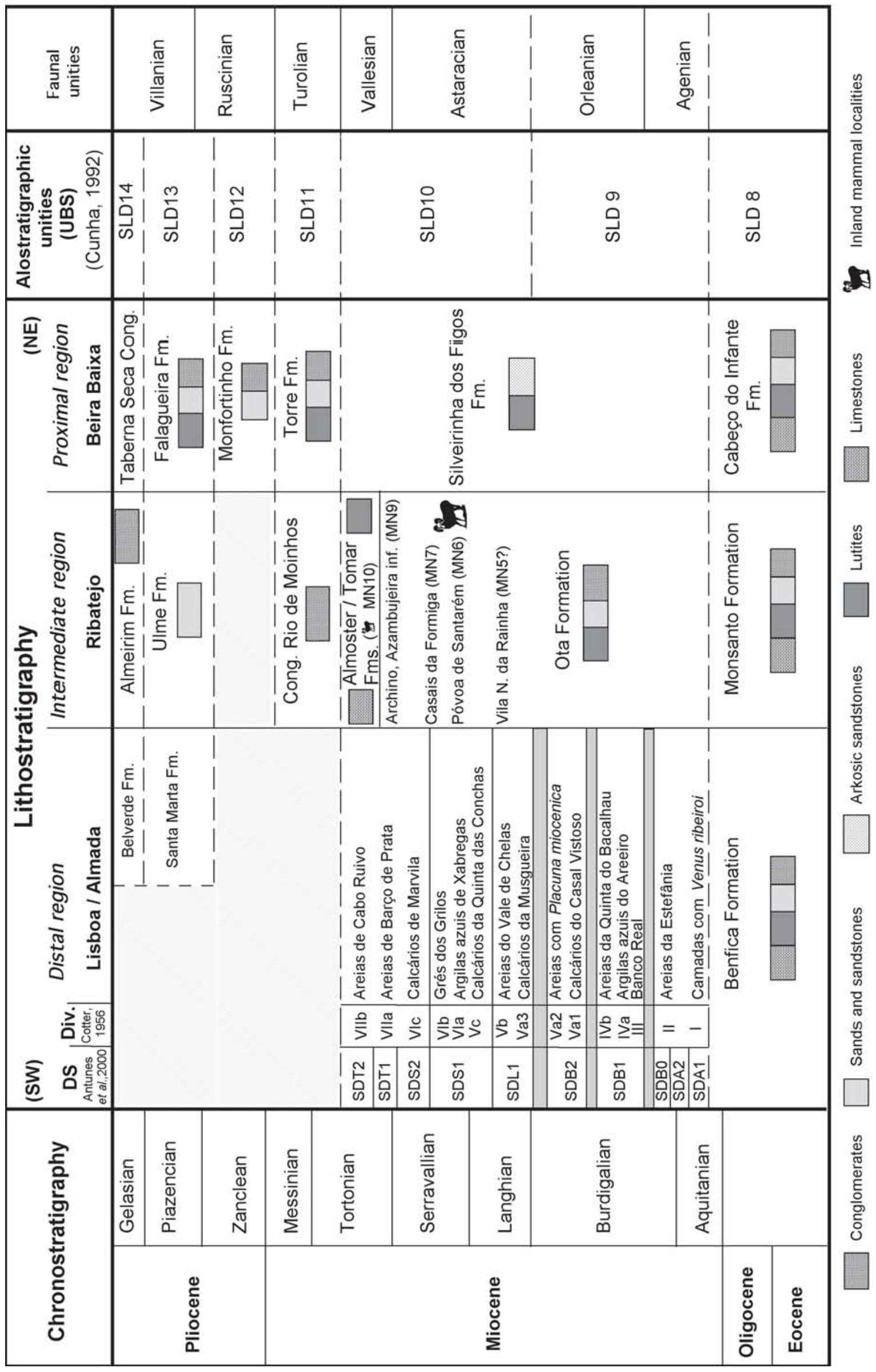

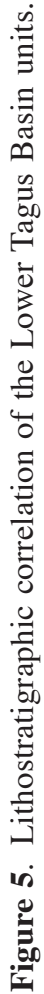



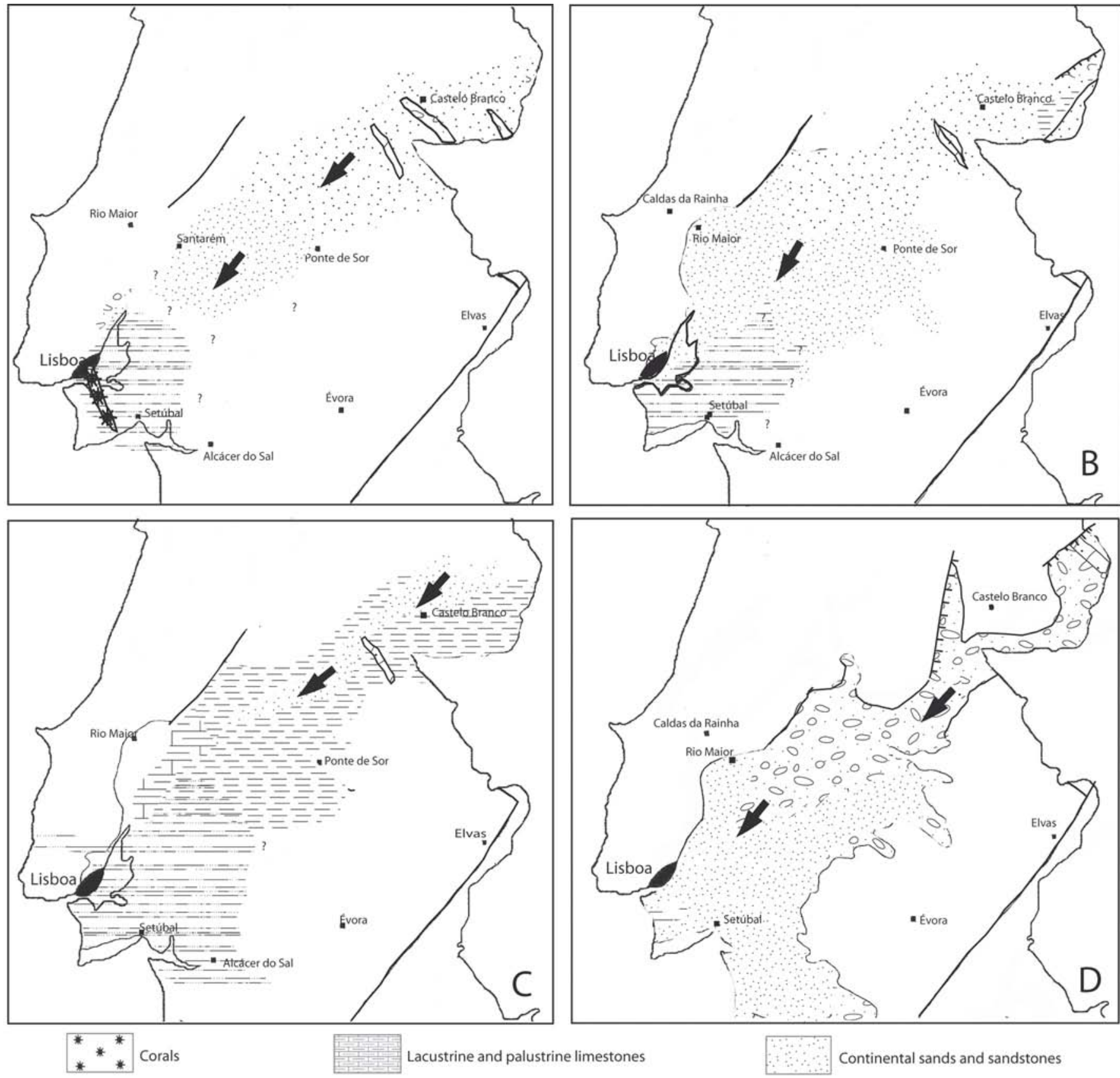

Lacustrine and palustrine limestones

Continental sands and sandstones

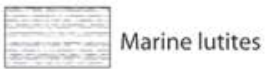

Continental clays

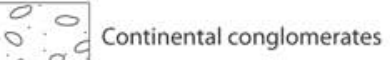

Figure 6. Paleogeographic maps concerning the Aquitanian (A), Upper Burdigalian (B), Serravallian to Lower Tortonian (C) and Piazencian (D) of the Lower Tagus Basin.

Antunes, M. T., Elderfield, H., Legoinha, P., Nascimento, A. and J. Pais 1999. A Stratigraphic framework for the Miocene from the Lower Tagus Basin (Lisbon, Setúbal Peninsula, Portugal). Depositional sequences, biostratigraphy and isotopic ages. Revista de la Sociedad Geologica de España, 12, 3-15.

Antunes, M.T. et Ginsburg, L. 1983. Les rhinocérotidés du Miocène de Lisbonne. Systématique, écologie, paléobiogéographie, valeur stratigraphique. Ciências da Terra (UNL), 7, 17-98.
Antunes, M.T., Ginsburg, L. et Mein, P. 1983. Mammifères miocènes de Azambujeira, niveau inférieur (Santarém, Portugal). Ciências da Terra (UNL), 7, 161-186.

Antunes, M.T., Ginsburg, L., Torquato, J.R. et Ubaldo, M. 1973. Age des couches à mammifères de la basse vallée du Tage (Portugal) et de la Loire moyenne (France). Comptes Rendus à l'Academie des Sciences de Paris, sér. D, 277, 2313-2316.

Antunes, M. T., Legoinha, P., Cunha, P. and Pais, J. 2000. High resolution stratigraphy and Miocene facies correla- 
tion in Lisbon and Setúbal Peninsula (Lower Tagus basin, Portugal). Ciências da Terra (UNL), 14, 183-190.

Antunes, M.T., Legoinha, P., Nascimento, A. and Pais, J. 1996b. The evolution of the lower Tagus basin (Lisbon and Setúbal Peninsula, Portugal from Lower to early Middle Miocene. Géologie de la France, B.R.G.M., 4, 59-77.

Antunes, M. T. et Mazo, A. 1983. Quelques mastodontes miocènes du Portugal. Ciências da Terra (UNL), 7, 115-128.

Antunes, M. T. et Mein, P. 1977. Contributions à la Paléontologie du Miocène moyen continental du Bassin du Tage. III - Mammifères - Póvoa de Santarém, Pero Filho et Chões (Secorio). Conclusions générales. Ciências da Terra (UNL), 3, 143-165.

Antunes, M. T. et Mein, P. 1979. Le gisement de Freiria de Rio Maior, Portugal, et sa faune de mammifères; nouvelle espèce de Rotundomys, conséquences stratigraphiques. Geobios, 12, 913-919.

Antunes, M. T. et Mein, P. 1981. Vertébrés du Miocène moyen de Amor (Leiria) / Importance stratigraphique. Ciências da Terra (UNL), 6, 169-188.

Antunes, M. T. and Pais, J. 1984. Climate during Miocene in Portugal and its evolution. Paléobiologie Continentale, XIV, 75-89.

Antunes, M.T. and Pais, J. 1992. The Neogene of Portugal. Ciências da Terra (UNL), número especial II, 13-24.

Antunes, M. T. and Pais, J. 1993. The Neogene of Portugal. Ciências da Terra (UNL), 12, 7-22.

Antunes, M.T. et Russel, D.E. 1981. Le gisement de Silveirinha (Bas Mondego, Portugal): la plus ancienne faune de Vertébrés éocènes connues en Europe. Comptes Rendus Académie des Sciences de Paris, Série D, 293, 1099-1102.

Antunes, M. T. et Torquato, J.R. 1969-70. Notes sur la Géologie et la Paléontologie du Miocène de Lisbonne. VI - La coupe de Quinta da Silvéria (Helvétien Vb et Vc): stratigraphie et évolution morphologique. Boletim da Sociedade Geológica de Portugal, XVII,1-30.

Antunes, M.T. et Zbyszewski, G. 1973. Le Méotien-Pontien de la basse vallée du Tage (r.droite), Portugal. Essai de synthèse biostratigraphique. Boletim da Sociedade Geológica de Portugal, XVIII, 203-217.

Azevêdo, M.T.M. 1983. O sinclinal de Albufeira, evolução pós-miocénica e reconstituição paleogeográfica. Dissertação doutoramento, Universidade de Lisboa, 302 pp.

Barbosa, B. 1995. Alostratigrafia e litostratigrafia das unidades continentais da Bacia terciária do baixo tejo. Relações com o eustatismo e a tectónica. Dissertação de Doutoramento, Universidade de Lisboa, 253 pp.

Barbosa, B. e Pena dos Reis, R. 1989. Litostratigrafia e modelo deposicional dos sedimentos aluviais do Neogénico superior da Bacia do Tejo (Tomar-Lavre), Portugal. Comunicações dos Serviços Geológicos de Portugal, 75, 89-97.

Barbosa, B. e Pena dos Reis, R. 1996. Geometrias de enchimento, sistemas deposicionais e organização estratigráfica do pliocénico continental da Bacia Terciária do Baixo Tejo (Portugal). Comunicações dos Serviços Geológicos de Portugal, 82, 51-86.
Barra, A. P., Barbosa, B., Martins, A. A. e Pena dos Reis, R. 2000. Depósitos neogénicos continentais da área de Vila de Rei (Portugal Central). Significado regional. Ciências da Terra (UNL), 14, 163-170.

Carvalho, A.M. 1968. Contribuição para o conhecimento geológico da bacia terciária do Tejo. Memórias dos Serviços Geológicos de Portugal, 15, 210 pp.

Choffat, P. 1950. Géologie du Cenozoïque du Portugal. Comunicações dos Serviços Geológicos de Portugal, XXX, suplemento, $183 \mathrm{pp}$.

Cotter, J.C.B. 1956. O Miocénico marinho de Lisboa. Comunicações dos Serviços Geológicos de Portugal, XXXVI, suplemento, 170 pp.

Cunha, P. P. 1992a. Estratigrafia e sedimentologia dos depósitos do Cretácico Superior e Terciário de Portugal Central, a leste de Coimbra. Tese de doutoramento, Universidade de Coimbra, 262 pp.

Cunha, P. P. 1992b. Establishment of unconformity-bounded sequences in the Cenozoic record of the western Iberian margin and syntesis of the tectonic and sedimentary evolution in central Portugal during Neogene. Abstracts of the First Congress R.C.A.N.S. - "Atlantic General Events During Neogene”, Lisboa, 33-35.

Cunha, P. P. 1996. Unidades litostratigráficas do Terciário da Beira-Baixa (Portugal). Comunicações do Instituto Geológico e Mineiro, 82, 87-130.

Cunha, P. P. 2000. Paleoalterações e cimentações nos depósitos continentais terciários de Portugal central: importância na interpretação de processos antigos. Ciências da Terra (UNL), 14, 145-154.

Cunha, P. P., Barbosa, B. P. and Pena dos Reis, R. 1993. Synthesis of the Piacenzian onshore record between the Aveiro and Setúbal parallels (western portuguese margin). Ciências da Terra (UNL), 12, 35-43.

Diniz, F. 1967. Une flore tertiaire de caractère Méditerranéen au Portugal. Revue of Palaeobotany and Palynology, 5, 263-268.

Diniz, F. 1984. Apports de la palynologie à la connaissance du Pliocène portugais. Rio Maior, un bassin de réference pour l'histoire de la flore, de la végétation et du climat de la façade atlantique de l'Europe meridionale. Thèse, Université Sciences Techniques du Languedoc, Montpellier, $230 \mathrm{pp}$.

Diniz,F. et Sivak, J. 1979. Informations chronologiques sur les dépôts de Rio Maior (Portugal) à partir de l'étude de la microflore. Paléobiologie continentale, X, 1-9.

Dollfus, G., Cotter, J. C. B. et Gomes, J.P. 1903-1904. Mollusques Tertiaires du Portugall Planches de Céphalopodes, Gastéropodes et Pélécypodes laissées par F.A.Pereira da Costal accompagnées d'une explication sommaire et d'une esquisse géologique. Imprimerie de l'Académie Royale des Sciences, Lisbonne, 1-44.

Eschwege, G. B. de 1831. Memória geognostica ou Golpe de vista do Perfil das estratificações das differentes róchas, de que he composto o terreno desde a Serra de Cintra na linha Noroeste a Sodoeste até Lisboa, atravessando o Tejo até à Serra da Arrabida, e sobre a sua idade relativa. Memorias da Acadademia Real das Sciencias de Lisboa, XI, 253-280. 
Gaudant, J. 1977. Contributions à la Paléontologie du Miocène moyen continental du Bassin du Tage. II - Observations sur les dents pharyngiennes de poissons cyprinidés Póvoa de Santarém. Ciências da Terra (UNL), 3, 129-141.

Haq, B. U., Hardenbol, J. and Vail, P. R. 1987. Chronology of fluctuating sea levels since the Triassic. Science, 235, 1156-1166.

Heer, O. 1881. Contributions à la flore fossile du Portugal. Memoire des Section des travaux Géologiques du Portugal, 1-51.

Hernández-Pacheco, F. y Crusafont Pairó, M. 1960. Primera caracterización paleontológica del Terciario de Extremadura. Boletin de la Real Sociedad Española Historia Naturale, Sec. Geológica, 58, 275-282.

Lauriat-Rage, A., Brébion, P., Cahuzac, B., Chaix, C., Ducasse, O., Ginsburg, L., Janin, M.-C., Lozouet, P., Margerel, J., Nascimento, A., Pais, J., Poignant, A., Pouyet, S. and Roman, J. 1993. Palaeontological data about the climatic trends from Chattian to present along the Northeastern Atlantic frontage. Ciências da Terra (UNL),12, 167-179.

Legoinha, P. 2001. Biostratigrafia de foraminíferos do Miocénico de Portugal. Dissertação de Doutoramento, Universidade Nova de Lisboa, 238 pp.

Legoinha, P., Sousa, L., Pais, J., Ferreira, J. and Amado, A.R. 2002. Miocene lithological, foraminiferal and palynological data from the Belverde borehole (Portugal). XVIII Jornadas de la Sociedad Española de Paleontologia, II Congresso ibérico do Paleontologia, Interim-Colloquium RCANS. Libro de resúmenes, 196-197.

Martins, A., Barbosa, B. e Reis, R.P. 1998. Os Conglomerados de Rio de Moinhos (Abrantes - Portugal Central). Actas V Congresso Nacional de Geologia, Comunicações do Instituto Geológico e Mineiro, 84, 142-144.

Pais, J. 1972. Fósseis de Quercus suber L. provenientes de formações cenozóicas continentais do Alentejo. Boletim do Museu e Laboratório Mineralógico e Geológico da Faculdade de Ciências de Lisboa, 13, 35-41.

Pais, J. 1973. Vegetais fósseis de Ponte de Sor. Boletim da Sociedade Geológica de Portugal, XVIII, 123-135.

Pais, J. 1978. Contributions à la Paléontologie du Miocène moyen continental du Bassin du Tage. V - Végétaux de Póvoa de Santarém (note preliminaire). Ciências da Terra (UNL), 4, 103-108.

Pais, J. 1979. Végétation de la basse vallée du Tage (Portugal) au Miocène. Annales Geologiques de Pays Helleniques, vol. h.s., fasc., II, 933-942.

Pais, J. 1981. Contribuição para o conhecimento da vegetação miocénica da parte ocidental da bacia do Tejo. Dissertação de Doutoramento, Universidade Nova de Lisboa, 328 pp.

Pais, J. 1986. Évolution de la végétation et du climat pendant le Miocène au Portugal. Ciências da Terra (UNL), 8, 179-191.

Pais, J. 1987. Macrorrestos de gimnospérmicas dos diatomitos de Rio Maior (Portugal). Volumen Homenagem $O$. Veiga Ferreira. Ed. Delta, Lisboa, 51-66.

Pais, J. 1989. Evolução do coberto florestal em Portugal no
Neogénico e no Quaternário. Comunicações dos Serviços Geológicos de Portugal, 75, 67-72.

Pais, J. 1991. Caules de Vila Velha de Rodão: Annonoxylon teixeirae Pais 1973. Boletim Informativo do Núcleo Regional de Investigação Arqueológica, Vila Velha de Rodão, 7, 1-2.

Pais, J. 1999. História geológica da Península de Setúbal nos últimos 20 milhões de anos. Guia de visita de campo integrada. Programa Ciência Viva, Geologia no Verão. Centro de Estudos Geológicos, Monte de Caparica, 21 pp.

Pais, J., Pais, C., Pereira, V. e Barbosa, B. 1999. Areias de Vale de Santarém. Estratigrafia e palinologia. Ciências da Terra (UNL), 13, 23-34.

Pais, J., Silva Lopes, C., Legoinha, P., Ramalho, E., Ferreira, J., Ribeiro, I., Amado, A.R., Sousa, L., Torres, L., Baptista, R. and Reis, R. P. 2002. The Belverde Borehole (Lower Tagus Basin, Setúbal Peninsula, Portugal). XVIII Jornadas de la Sociedad española de Paleontologia, II Congresso ibérico do Paleontologia, Interim-Colloquium RCANS. Libro de resúmenes, 198-199.

Ribeiro, A., Antunes, M.T., Ferreira, M.P., Rocha, R., Soares, A.F., Zbyszewski, G., Moitinho de Almeida, F., Carvalho, D. et Monteiro, J.H. 1979. Introduction à la géologie générale du Portugal. Serviços Geológicos de Portugal, 3-114.

Ribeiro, C. 1878. Des Formations tertiaires du Portugal. Compte Rendu Sténographique du Congrès International de Géologie tenu à Paris du 29 au 31 Août et du 2 au 4 Septembre 1878, Extraît, 1-9.

Ribeiro, C. 1880. Des formations tertiaires du Portugal. Congrès International de Géologie de 1878, Paris, 21, 205-214.

Roman, F. et Torres, A. 1907. Le Néogène continental de la basse vallée du Tage (rive droite). 1re partie - Paléontologie par F. Roman avec une note sur les empreintes végétales de Pernes par M.Fliche; 2e partie - Stratigraphie par A. Torres. Memorias da Comissão dos Serviços Geológicos de Portugal,1re partie, 1-88, 2e partie, 89-109.

Sharpe, D. 1834. On the strata in the immediate neighbourhood of Lisbon and Oporto. Proceedings of the Geological Society, 1 [1826-1833], 394-396.

Sharpe, D. 1841. On the geology of the neighbourhood of Lisbon. Transactions of the Geological Society, London, VI, sections 1, 9, 11, 12 and 13.

Silva, J.B. de A. e 1817. Memoria sobre a nova mina de ouro da outra banda do Tejo. Historia e Memorias da Academia Real das Sciencias de Lisboa, Memorias dos Socios, 5, 140-152.

Smith, J. 1847. On the Age of the Tertiary Beds of the Tagus, with a Catalogue of the Fossils. Proceedings of the Geological Society, London, III, 410-423.

Soulié-Märsh, I. 1978. Contributions à la Paléontologie du Miocène moyen continental du Bassin du Tage. IV Charophytes - Póvoa de Santarém, Pero Filho e Tremês. Ciências da Terra (UNL), 4, 91-102.

Teixeira, C. 1942a. Présence du Lygodium gaudini Heer dans quelques formations tertiaires du Portugal. Publicações do Museu e Laboratório Mineralógico e Geológico da Faculdade de Ciências do Porto, $1^{\mathrm{a}}$ sér, 25, 8 pp. 
Teixeira, C. 1942b. Sobre a existência de Palmeiras do género Sabal no Pliocénico português. Boletim da Sociedade Portuguesa de Sciencias Naturais, 14 (28), 135-138.

Teixeira, C. 1944a. Pinheiro fóssil do Pliocénico de Rio Maior. Boletim da Sociedade Broteriana, $2^{a}$ sér., 19, 201209.

Teixeira, C. 1944b. Sequóia fóssil do Cenozóico português. Publicações do Museu e Laboratório Mineralógico e Geológico da Faculdade de Ciências do Porto, $2^{\mathrm{a}}$ sér., 33, $1-8$.

Teixeira, C. 1944c. A expansão do Pinus sylvestris L. no Sudoeste da Europa e a mudança climática dos fins do Pliocénico. Publicações do Museu e Laboratório Mineralógico e Geológico da Faculdade de Ciências do Porto, $2^{\mathrm{a}}$ sér., 35, 1-10.

Teixeira, C. 1944-1947. Flora fóssil de Archino (Alenquer). Boletim da Sociedade Portuguesa de Ciências Naturais, 16, 71-74.

Teixeira, C. 1946. Revisão da flora fóssil de Azambuja. Publicações do Museu e Laboratório Mineralógico e Geológico da Faculdade de Ciências de Lisboa, $4^{\mathrm{a}}$ série, 14, 121-134.

Teixeira, C. 1947a. Flora de Sra. de Saúde. Santarém. Comunicações dos Serviços Geológicos de Portugal, XXXVIII, 145-147.

Teixeira, C. 1947b. Flora pliocénica de Montijo. Comunicações dos Serviços Geológicos de Portugal, XXXVIII, 213-216.

Teixeira, C. 1949. Flora fóssil do Pliocénico do Alfeite. Comunicações dos Serviços Geológicos de Portugal, XXX, 43-58.

Teixeira, C. 1952a. Flora fóssil das argilas de Vale de Carros (Alpiarça). Comunicações dos Serviços Geológicos de Portugal, XXXII, 11-14.

Teixeira, C. 1952b. Flora fóssil do Pliocénico de Vale de Santarém. Comunicações dos Serviços Geológicos de Portugal, XXXIII, 51-64.

Teixeira, C. 1954. A palmeira anã - Chamaerops humilis L. - no Pliocénico português. Boletín de la Real Sociedad Española de Historia Natural, Volumen homenaje a F. Hernandez Pacheco, 659-662.

Teixeira, C. 1973. Quelques cônes de pin fossiles du Miocène portugais. Boletim da Sociedade Geológica de Portugal, XVIII, 151-154.

Teixeira, C. 1973-74. Sur la présence de Pittosporum dans le Pliocène du Portugal. Revista da Faculdade de Ciências de Lisboa, $2^{\mathrm{a}}$ série, C, 11, 599-601.

Teixeira, C. 1979. Plio-plistocénico de Portugal. Comunicações dos Serviços Geológicos de Portugal, LXV, 35-46.

Teixeira, C. e Pais, J. 1976. Introdução à paleobotânica. As grandes fases da evolução dos vegetais. Ed. autores, Lisboa, 210 pp.

Truc, G. 1977. Contributions à la Paléontologie du Miocène moyen continental du Bassin du Tage. I - Quelques mollusques - Pero Filho, Póvoa de Santarém, Sítio do Mirante. Ciências da Terra (UNL), 3, 121-127.
Zbyszewski, G. 1941. Les problèmes du Néogène continental de la basse vallée du Tage (rive droite). X Congreso de la Asociación Española para el Progreso de las Ciencias, Zaragoza, Diciembre 1940, 25 pp.

Zbyszewski, G. 1943. Élements pour servir à l'étude du Pliocène marin au Sud du Tage: la faune des couches supérieures d'Alfeite. Comunicações dos Serviços Geológicos de Portugal, XXIV,125-156.

Zbyszewski, G. 1946. Étude géologique de la région d'Alpiarça. Comunicações dos Serviços Geológicos de Portugal, XXVII,145-267.

Zbyszewski, G. 1947. Etude géologique de la région d'Almeirim. Comunicações dos Serviços Geológicos de Portugal, XXVIII, 217-263.

Zbyszewski, G. 1953. Carta Geológica da Portugal na escala 1:50.000, Notícia Explicativa da folha 31-A, Santarém. Serviços Geológicos de Portugal, 16 pp.

Zbyszewski, G. 1954a. L'Aquitanien supérieur de Lisbonne et du Ribatejo. Comunicações dos Serviços Geológicos de Portugal, XXXV, 99-154.

Zbyszewski, G. 1954b. Étude géologique de la région de Santarém. Comunicações dos Serviços Geológicos de Portugal, XXXV, 193-225.

Zbyszewski, G. 1957. Le Burdigalien de Lisbonne. Comunicações dos Serviços Geológicos de Portugal, XXXVIII, 91-215.

Zbyszewski, G. 1962. Considérations sur la position stratigraphique de l'Aquitanien portugais. Comunicações dos Serviços Geológicos de Portugal, XLVI, 297-316.

Zbyszewski, G. 1963. Carta geológica dos arredores de Lisboa na escala de 1/50000. Notícia Explicativa da folha 4 (Lisboa). Serviços Geológicos de Portugal, 93 pp.

Zbyszewski, G. 1964a. L'Aquitanien du Portugal et sa place stratigraphique. Cursillos y Conferencias, Instituto Lucas Mallada, C.S.I.C., 9, 9-12.

Zbyszewski, G. 1964b. Les rapports entre les milieux miocènes marins et continentaux au Portugal. Cursillos y Conferencias, Instituto Lucas Mallada, C.S.I.C., 9, 103-108.

Zbyszewski, G. 1965. Observações acerca da idade de três jazidas da vertebrados terciários. Boletim da Academia das Ciências de Lisboa, XXXVII, 218-230.

Zbyszewski, G. 1967a. Contributions à l'étude du Miocène de la serra da Arrábida. Comunicações dos Serviços Geológicos de Portugal, LI, 37-148.

Zbyszewski, G. 1967b. Le Mastodonte du "Pliocène" da Santarém. Comunicações dos Serviços Geológicos de Portugal, LII, 11-15.

Zbyszewski, G. 1967c. Estudo da Bacia da Rio Maior. Estudos Notas e Trabalhos do Serviço de Fomento Mineiro, XVII(3-4), 105 pp.

Zbyszewski, G. 1968. Uma ocorrência de lignito em Vale de Santarém. Boletim de Minas, 5, 1-7.

Manuscrito recibido: 20 de febrero, 2003 Manuscrito aceptado: 2 de septiembre, 2004 